\title{
Joseph Bédier, Philologie et humanisme. Articles et préfaces inédits en volume
}

\section{Walter Meliga}

\section{(2) OpenEdition}

1 Journals

\section{Edizione digitale}

URL: http://journals.openedition.org/studifrancesi/3621

DOI: 10.4000/studifrancesi.3621

ISSN: 2421-5856

\section{Editore}

Rosenberg \& Sellier

\section{Edizione cartacea}

Data di pubblicazione: 1 décembre 2012

Paginazione: 537

ISSN: 0039-2944

\section{Notizia bibliografica digitale}

Walter Meliga, «Joseph Bédier, Philologie et humanisme. Articles et préfaces inédits en volume», Studi Francesi [Online], 168 (LVI | III) | 2012, online dal 30 novembre 2015, consultato il 05 mars 2021. URL: http://journals.openedition.org/studifrancesi/3621 ; DOI: https://doi.org/10.4000/studifrancesi.3621

Questo documento è stato generato automaticamente il 5 mars 2021.

\section{(c) $(1) \&$}

Studi Francesi è distribuita con Licenza Creative Commons Attribuzione - Non commerciale - Non opere derivate 4.0 Internazionale. 


\title{
Joseph Bédier, Philologie et humanisme. Articles et préfaces inédits en volume
}

\author{
Walter Meliga
}

\section{NOTIZIA}

JOSEPH BÉDIER, Philologie et humanisme. Articles et préfaces inédits en volume, Choix, notices et avant-propos d'Alain CORBELLARI, Paris, Classiques Garnier, 2010 («Recherches littéraires médiévales», 4. «Magistralia. Leçons et lectures», 1), pp. 493.

1 Il volume raccoglie un numero consistente di contributi isolati di Joseph Bédier, mai raccolti prima in volume, di indubbia importanza, non soltanto per la statura scientifica del suo autore, ma anche per il carattere e la qualità degli scritti. Sono raccolti lavori di letteratura medievale (epica, lirica, generi cortesi e altro) ma anche di letteratura moderna e, di particolare interesse, di storia degli studi letterari e filologici, lungo tutta la carriera scientifica di Bédier, dal 1886 al 1937. La prefazione di Alain Corbellari (studioso di Bédier) permette di comprendere molto bene il carattere complesso dell'attività e della personalità di Bédier e la sua posizione all'interno della trionfante filologia romanza francese del primo trentennio del xx secolo. La raccolta è anche molto opportuna, giacché, come osserva ancora il curatore, Bédier è soprattutto l'autore di alcuni grandi libri, che hanno marcato il successivo sviluppo degli studi di filologia romanza: la riscoperta dei suoi articoli permette così di meglio comprendere la sua figura di intellettuale, non solo filologo e storico insigne ma anche letterato e critico di grande finezza e di spiccata attenzione per i valori poetici e per le suggestioni della riscoperta letteratura medievale. 